\title{
PENINGKATAN KETERAMPILAN MENULIS SURAT RESMI SISWA SMP NEGERI 2 JABUNG LAMPUNG TIMUR DENGAN PENDEKATAN KONTEKSTUAL
}

\author{
Oleh: Safitri Yani, Dian Nuzulia Armariena \\ (Guru SMPN 2 JABUNG, Universitas PGRI Palembang)
}

Emailsafitri@gmail.com, diannuzulia@ univpgri-palembang.ac.id

\begin{abstract}
Abstrak
Penelitian ini bertujuan untuk mengetahui peningkatan keterampilan menulis surat resmi siswa kelas VII SMP Negeri 2 JABUNG Lampung Timur dengan pendekatan kontekstual. Metode yang digunakan adalah penelitian tindakan kelas. Subjek penelitian ini adalah siswa kelas VII SMP Negeri 2 JABUNG Lampung Timur, dengan jumlah siswa sebanyak 30 orang. Teknik pengumpulan data yang digunakan adalah teknik tes, observasi, dan angket. Berdasarkan hasil penelitian, penggunaan pendekatan kontekstual pada pembelajaran Bahasa Indonesia pada kompetensi menulis surat resmi dalam meningkatkan keterampilan siswa menulis surat resmi. Hal tersebut dapat dilihat dari data nilai pada setiap siklus yang menunjukkan peningkatan yang cukup signifikan. Sehingga penggunaan pendekatan kontekstual dapat meningkatkan keterampilan siswa dalam menulis surat resmi. Hal ini dapat dilihat dari hasil siklus I sampai siklus II. Persentase jumlah siswa yang tuntas pada saat prasiklus adalah 8 siswa atau 26,6\%. Setelah dilakukan tindakan pada siklus I, meningkat menjadi 17 siswa atau 56,6\% dengan nilai rata-rata 69,4. Kemudian pada siklus II jumlah siswa yang tuntas meningkat menjadi 29 siswa atau 96,7\% dengan nilai rata-rata 76,8 .
\end{abstract}

Kata Kunci : Menulis Surat Resmi, Pendekatan Kontekstual

\section{IMPROVING SKILLS OF AUTHORIZED WRITING OF OFFICIAL STUDENTS OF JUNIOR HIGH SCHOOL 2 JABUNG LAMPUNG TIMUR WITH CONTEXTUAL APPROACH}

\begin{abstract}
This study aims to find out the improvement in writing skills for the official letter of VII grade students of SMP Negeri 2 JABUNG, East Lampung with a contextual approach. The method used is classroom action research. The subjects of this study were Grade VII students of SMP Negeri 2 JABUNG, East Lampung, with a total of 30 students. Data collection techniques used were test, observation, and questionnaire techniques. Based on the results of the study, the use of contextual approaches to learning Indonesian on the competence of writing official letters in improving the skills of students writing official letters. This can be seen from the value data in each cycle that shows a significant increase. So the use of contextual approaches can improve student skills in writing official letters. This can be seen from the results of cycle I to cycle II. The percentage of students
\end{abstract}


who completed the pre-cycle was 8 students or $26.6 \%$. After taking action in the first cycle, it increased to 17 students or $56.6 \%$ with an average value of 69.4. Then in the second cycle the number of students who completed increased to 29 students or $96.7 \%$ with an average value of 76.8 .

Keywords: Writing an Official Letter, Contextual Approach

\section{A. PENDAHULUAN}

Dalam kehidupan manusia tentu tak pernah lepas dari kegiatan menulis. Dalam menyampaikan informasi banyak orang lebih memilih menyampaikan melalui tulisan, karena mereka beranggapan bahwa informasi dalam bentuk tulisan akan lebih mudah dipahami oleh orang lain dibandingkan dalam bentuk lisan. Menurut Wiyanto (2004:1) kata menulis memiliki dua arti. Pertama, menulis berarti mengubah bunyi yang dapat didengar menjadi tanda-tanda yang dapat dilihat. Kedua, kata menulis mempunyai arti kegiatan mengungkapkan gagasan secara tertulis.

Djuharie dkk. (2001:15) menyatakan bahwa surat resmi adalah surat yang dibuat oleh suatu instansi, organisasi, atau lembaga perusahaan tertentu yang ditujukan kepada seseorang atau lembaga tertentu lainnya, serta keberadaan instansi, lembaga, organisasi, dan perusahaan tersebut disahkan secara hukum.

Pendekatan kontekstual merupakan sebuah pendekatan yang digunakan oleh seorang guru dalam proses pembelajaran yang disesuaikan dengan keadaan lingkungan siswa. Sanjaya (2008:225) menyatakan pendekatan kontekstual dalam pengajaran dan pembelajaran adalah suatu strategi pembelajaran yang menekankan kepada proses keterlibatan siswa secara penuh untuk dapat menemukan materi yang dipelajari dan menghubungkannya dengan situasi kehidupan nyata sehingga mendorong siswa untuk dapat menerapkannya dalam kehidupan mereka.

Masalah dalam penelitian ini adalah bagaimanakah peningkatan keterampilan menulis surat resmi siswa kelas VII SMP Negeri 2 JABUNG Lampung Timur dengan pendekatan kontekstual. Penelitian ini bertujuan untuk mengetahui peningkatan keterampilan menulis surat resmi siswa kelas VII SMP Negeri 2 JABUNG Lampung Timur dengan pendekatan kontekstual. 
Armariena (2017, 2019) menyatakan bahwa menulis dipergunakan, melaporkan/ memberitahukan, dan memengaruhi; dan maksud serta tujuan seperti itu hanya dapat dicapai dengan baik oleh orang-orang yang dapat menyusun pikirannya dan mengutarakannya dengan jelas, kejelasan ini bergantung pada pikiran, organisasi, pemakaian kata-kata, dan struktur kalimat. Selanjutnya Nurjamal (2011:69) menyatakan menulis merupakan kemampuan seseorang dalam mengemukakan gagasan, perasaan, dan pikiran-pemikirannya kepada orang atau pihak lain dengan menggunakan media tulisan.

Surat secara umum ditinjau dari segi bentuk, isi, dan bahasanya digolongkan menjadi tiga yaitu surat pribadi, surat dinas, dan surat niaga. Sedangkan berdasarkan pemakaiannya surat dibagi atas tiga jenis yaitu surat pribadi, resmi, dan dinas. Bentuk penulisan surat atau format surat yang lazim dipergunakan ada 5 bentuk, yaitu, 1) bentuk lurus penuh (full block style); 2) bentuk lurus (block style); 3) bentuk setengah lurus (semiblock style); 4) bentuk lekuk (indented style); 5) Bentuk Lekuk dan gerigi (Indented Style); 6) bentuk paragraf menggantung (hanging paragrap).

Djuharie dkk. (2001:15) menyatakan bahwa surat resmi adalah surat yang dibuat oleh suatu instansi, organisasi, atau lembaga perusahaan tertentu yang ditujukan kepada seseorang atau lembaga tertentu lainnya, serta keberadaan instansi, lembaga, organisasi, dan perusahaan tersebut disahkan secara hukum.

Pendekatan konstektual adalah suatu strategi pembelajaran yang menekankan kepada proses keterlibatan siswa secara penuh untuk dapat menemukan materi yang dipelajari dan menghubungkannya dengan situasi kehidupan nyata sehingga mendorong siswa untuk dapat menerapkannya dalam kehidupan mereka (Sanjaya, 2008:225).

Langkah-langkah dalam pendekatan kontekstual adalah sebagai berikut (Hernowo, 2005:93). 1) Guru mengarahkan siswa sedemikian rupa dapat mengembangkan pemikirannya untuk melakukan kegiatan belajar yang bermakna, berkesan, baik dengan cara meminta siswa untuk bekerja sendiri dan mencari serta menemukan sendiri jawabannya. 2) Dengan bimbingan guru, siswa diajak untuk menemukan suatu fakta dari permasalahan yang disajikan guru/dari materi yang 
diberikan guru. 3) Memancing reaksi siswa untuk melakukan pertanyaanpertanyaan dengan tujuan untuk mengembangkan rasa ingin tahu siswa. 4) Guru membentuk kelas menjadi beberapa kelompok umtuk melakukan diskusi, dan tanya jawab. 5) Guru mendemonstrasikan ilustrasi/gambaran materi dengan model atau media yang sebenarnya. 6) Guru bersama siswa melakukan refleksi atas kegiatan yang telah dilakukan. 7) Guru melakukan evaluasi, yaitu menilai kemampuan siswa yang sebenarnya.

\section{B. METODOLOGI PENELITIAN}

Peningkatan keterampilan menulis surat resmi dalam penelitian ini adalah usaha memecahkan persoalan dan mencari jalan keluar untuk meningkatkan kemampuan siswa dalam menulis surat resmi dengan pendekatan kontekstual dengan subjek siswa kelas VII A SMP Negeri 2 JABUNG Lampung Timur berjumlah 30 siswa, laki-laki berjumlah 14 dan 16 perempuan dengan menggunakan pendekatan penelitian tindakan kelas.

Pengumpulan data dalam penelitian ini menggunakan teknik tindakan, teknik tes, dan teknik angket. Teknik tindakan ada empat langkah atau tahap, yaitu perencanaan, tindakan, observasi, dan refleksi.Teknik tes menggunakan tes tertulis Teknik angket diberikan pada tahap studi pendahuluan, subjek masingmasing diberi delapan pertanyaan yang ditujukan kepada siswa kelas VII SMP Negeri 2 JABUNG Lampung Timur.

Teknik analisis data tes mengukur kemampuan menulis surat resmi masingmasing siswa dengan mengukur indikator yang digunakan. Data angket siswa dianalisis berdasarkan persentase frekuensi relatif dengan rumus: $\mathrm{p}=\frac{f}{N} \times 100 \%$ ( $\mathrm{p}=$ Persentase, $f=$ Frekuensi, dan $N=$ Jumlah sampel). Data observasi dianalisis berdasarkan hasil observasi, yang berupa semua kejadian selama proses tindakan diobservasi dan dicatat, dianalisis, dideskripsikan, diinterpretasikan, dan disimpulkan.

\section{HASIL PENELITIAN DAN PEMBAHASAN}


Untuk memperoleh data mengenai peningkatan keterampilan menulis surat resmi siswa diminta membuat surat resmi yang terkait dengan apa yang telah diketahui dan peristiwa yang terjadi di sekelilingnya dalam waktu 1 jam pelajaran. Tes awal dilakukan pada hari Selasa tanggal 20 Oktober 2019. Peserta tes sebanyak 30 siswa. Hasil evaluasi pada tes awal jumlah siswa yang memperoleh nilai $\geq 70$ mencapai 8 siswa dari total 30 siswa dan yang memperoleh nilai $<70$ sebanyak 22 siswa. Pencapaian hasil tes belum sesuai kriteria ketuntasan minimal yakni $26,7 \%$.

\section{Siklus I}

Sesuai dengan karakteristik penelitian tindakan kelas, hasil proses pembelajaran dalam siklus pertama yang dilakukan dalam dua kali pertemuan diperoleh data pencapaian keberhasilan siswa menulis surat resmi dengan pendekatan kontekstual. Penilaian yang diberikan kepada siswa adalah kemampuan menulis surat resmi dengan pendekatan kontekstual yaitu ketepatan penggunaan kosa kata, isi, mekanisme penulisan yang telah ditetapkan. Setiap unsur itu diberi bobot penilaian. Nilai yang diberikan kepada siswa berdasarkan ketepatan penggunaan kosa kata, isi, mekanisme penulisan dalam surat resmi yang dibuat siswa.

Siklus I dilakukan sebagai usaha untuk mengatasi masalah yang ditemukan pada saat observasi awal. Pendekatan kontekstual merupakan langkah yang diambil untuk meningkatkan keterampilan menulis surat resmi siswa kelas VII SMP Negeri 2 JABUNG Lampung Timur. Siklus I dilakukan sebagai usaha untuk mengatasi masalah yang ditemukan pada saat observasi awal yang dilakukan dalam dua kali pertemuan. Pertemuan pertama pada hari Kamis tanggal 22 Oktober 2019 selama 2 jam pelajaran, pukul 07.30-08.40 WIB. Pertemuan kedua pada hari Selasa tanggal 27 Oktober 2019, pukul 07.30-08.40 WIB.

Observasi dilakukan meliputi observasi aktivitas guru dengan apersepsi, penjelasan materi, penjelasan model pembelajaran sampai dengan menyimpulkan dan menutup pelajaran. Observasi Aktivitas Siswa menunjukkan bahwa aktivitas siswa dikategorikan aktif atau kurang aktif. Nilai rata-rata dari hasil evaluasi 
siswa yaitu 69,4. Siswa yang telah mencapai KKM berjumlah 17 siswa, dengan kata lain baru $56,6 \%$.

Refleksi kegiatan adalah mengkaji hasil pelaksanaan siklus I. Dalam Siklus I belum ditemukan adanya peningkatan yang signifikan. Kelebihan dan kekurangan pada siklus I dijadikan acuan dalam melaksanakan siklus II. Keberhasilan yang diperoleh pada siklus I berupa adanya peningkatan keterampilan menulis surat resmi dengan pendekatan kontekstual Siswa Kelas VII SMP Negeri 2 JABUNG Lampung Timur yang dilihat dari hasil evaluasi siswa. Hal ini disebabkan oleh aktivitas guru yang telah sesuai dengan rencana pembelajaran.

Namun, meskipun terjadi peningkatan pada jumlah siswa yang mencapai ketuntasan belajar individual, ketuntasan belajar siswa secara klasikal masih belum tercapai yakni 70\%. Aktivitas belajar siswa pun masih belum maksimal, sebab masih terdapat satu aspek yang belum dicapai yakni ketepatan siswa dalam menggunakan kalimat resmi. Hal ini menyebabkan siswa menjadi kurang mampu dalam menyusun kata-kata untuk menuangkan ide dan perasannya dalam bentuk surat resmi dengan pendekatan kontekstual.

\section{Siklus II}

Siklus II dilaksanakan sesuai dengan hasil refleksi dari kekurangan dan kelebihan pada siklus I sebagai usaha perbaikan. Pertemuan pertama dilaksanakan pada hari Kamis tanggal 29 Oktober 2019. Pembelajaran dimulai pada pukul 07.30 WIB dan diakhiri pada pukul 08.40 WIB. Pertemuan kedua dilaksanakan pada hari Selasa tanggal 03 November 2019 pukul 07.30-08.40 WIB. Pembelajaran dimulai pada pukul 07.30 WIB dan diakhiri pada pukul 08.40 WIB.

Observasi aktivitas guru pada pembelajaran siklus II, diperoleh hasil observasi aktivitas guru, seluruh kegiatan peneliti selama proses pembelajaran berlangsung. Hasil observasi aktivitas siswa pada siklus II termasuk pada kategori sangat aktif. Hasil evaluasi pada siklus II jumlah siswa yang memperoleh nilai $\geq$ 70 mencapai 29 siswa dari total 30 siswa dan yang memperoleh nilai <70 sebanyak 1 siswa. Pencapaian hasil telah mencapai kriteria ketuntasan minimal yakni $96,7 \%$. 
Hasil analisis tersebut menjelaskan bahwa pembelajaran keterampilan menulis surat resmi dengan pendekatan kontekstual telah berhasil meningkatkan keterampilan siswa kelas VII SMP Negeri 2 JABUNG Lampung Timur. Hasil proses pembelajaran pada siklus II menunjukkan jauh lebih baik. Hasil ketuntasan belajar siswa lebih meningkat dan hasilnya sudah mencapai kriteria ketuntasan minimal yakni 96,7\%. Tindak lanjut setelah data diperoleh, peneliti dan guru kolaborator bersepakat untuk menghentikan sampai siklus II saja karena sudah terjadi peningkatan yang signifikan dan sudah menunjukkan perubahan yang berarti, baik dari pelaksanaan proses pembelajaran dan hasil belajar tentang keterampilan siswa menulis surat resmi siswa kelas VII SMP Negeri 2 JABUNG Lampung Timur dengan pendekatan kontekstual. Hasil refleksi pada siklus II yaitu (1) pelaksanaan pembelajaran yang dilakukan oleh guru kolaborator sudah mengacu pada RPP. Materi yang disampaikan sesuai yang telah direncanakan, (2) siswa sudah mengerti dengan bentuk dan jenis surat resmi, (3) guru lebih fokus membimbing siswa dan mengarahkan siswa dalam membuat surat, proses menulis, dan pascamenulis.

Berdasarkan analisis data tes pada siklus 1 dan siklus 2, diketahui bahwa siswa yang mendapat nilai < 70 yaitu 67 tergolong belum tuntas sebanyak 1 siswa atau 3,3\%, siswa yang mendapat nilai > 70 yaitu sebanyak 29 siswa atau 9,7\% dan mengalami peningkatan yang signifikan.

Dari data angket diperoleh data bahwa sebagaian besar siswa kelas VII SMP Negeri 2 JABUNG Lampung Timur; 1) menyenangi pembelajaran menulis surat resmi; 2) mengakui sering menulis surat resmi di luar jam pelajaran; 3) lebih mudah menggunakan pendekatan kontekstual dibandingkan dengan ceramah; 4) lebih suka menulis surat resmi dibanding menulis surat jenis lainnya; 5) lebih mudah menggunakan pendekatan kontekstual saat pembelajaran menulis surat resmi; 6) setuju untuk menggunakan pendekatan kontekstual saat pembelajaran menulis surat resmi; 7) menyatakan pendekatan kontekstual bermanfaat saat pembelajaran menulis surat resmi; 8) mengatakan tidak sulit menggunakan pendekatan kontekstual saat pembelajaran menulis surat resmi. 


\section{PEMBAHASAN}

Penelitian ini dilaksanakan pada tanggal 13 Oktober sampai dengan 23 Oktober 2019 bertempat di SMP Negeri 2 JABUNG Lampung Timur. Penelitian ini dilakukan pada siswa kelas VII SMP Negeri 2 JABUNG Lampung Timur. Penelitian ini menggunakan metode penelitian tindakan kelas. Pelaksanaan tindakan pada setiap siklus dibagi dalam empat kegiatan yaitu: perencanaan, pelaksanaan, observasi, evaluasi dan refleksi.

Adapun yang akan disiapkan pada tahap perencanaan yaitu melakukan analisis kurikulum untuk menentukan standar kompetensi dan kompetensi dasar yang akan disampaikan kepada siswa dengan menerapkan penggunaan pendekatan kontekstual, membuat rencana pembelajaran (RPP) yang sesuai dengan materi agar anak mudah memahami materi yang disampaikan, membuat lembar kerja siswa, menyusun alat evaluasi pembelajaran, dan menyiapkan lembar observasi siswa dan guru untuk melihat bagaimana situasi pembelajaran dengan menerapkan penggunaan pendekatan kontekstual.

Materi yang diajarkan adalah siswa dapat menyebutkan menentukan jenis dan bentuk surat. Pembelajaran ini dilaksanakan dengan menggunakan pendekatan kontekstual. Media penunjang yang digunakan pembelajaran ini adalah menggunakan surat resmi.

Perbaikan kelemahan keterampilan siswa menulis surat resmi dengan pendekatan kontekstual mendapat hasil memuaskan ketika perbaikan itu dilakukan dengan cara memberikan pelatihan kepada mereka. Pelatihan yang diberikan sebelum dilakukan tes dapat meningkatkan keterampilan siswa menulis surat resmi dengan pendekatan kontekstual. Peningkatkan keterampilan siswa dalam menulis surat resmi, dapat dilihat dari hasil menulis surat resmi baik dari prasiklus sampai siklus II. Pada siklus pertama nilai rata-rata dari hasil belajar siswa dalam keterampilan menulis surat resmi dengan pendekatan kontekstual yaitu 69,4. Sesuai dengan KKM (Kriteria Ketuntasan Minimal) mata pelajaran bahasa Indonesia adalah 70, maka siswa yang telah mencapai KKM berjumlah 17 siswa, dari total seluruh siswa yaitu 30 siswa yang mencapai ketuntasan belajar individu dengan kata lain 69,4\%. 
Ketuntasan belajar individu yang ditetapkan kelas VII SMP Negeri 2 JABUNG Lampung Timur untuk mata pelajaran Bahasa Indonesia adalah 70. pada siklus II jumlah siswa yang memperoleh nilai $\geq 70$ mencapai 29 siswa dari total 30 siswa. Sisanya memperoleh nilai $<70$ sebanyak 1 siswa. Hasil analisis tersebut menjelaskan bahwa pencapaian hasil ketuntasan belajar siswa pada pembelajaran menulis surat resmi dengan pendekatan kontekstual siswa kelas VII SMP Negeri 2 JABUNG Lampung Timur, di siklus II ini telah mencapai kriteria ketuntasan minimal klasikal yakni 96,7\%.

Dengan demikian dapat dikatakan pembelajaran menulis surat resmi dengan pendekatan kontekstual siswa kelas VII SMP Negeri 2 JABUNG Lampung Timur pada siklus II telah berhasil meningkatkan keterampilan siswa dalam menulis surat resmi. Pada siklus II diketahui bahwa siswa yang mendapat nilai < 70 yaitu 67 tergolong belum tuntas sebanyak 1 siswa atau 3,3\%, siswa yang mendapat nilai > 70 yaitu sebanyak 29 siswa atau 96,7\%. Berarti kemampuan siswa kelas VII SMP Negeri 2 JABUNG Lampung Timur menulis surat resmi dari siklus 1 sampai siklus 2 mengalami peningkatan yang signifikan. Persentase jumlah siswa yang tuntas pada saat prasiklus adalah 9 siswa atau 27\%. Setelah dilakukan tindakan pada siklus I, meningkat menjadi 17 siswa atau 56,6\% dengan nilai rata-rata 71,9. Kemudian pada siklus II jumlah siswa yang tuntas meningkat menjadi 29 siswa atau $96,7 \%$ dengan nilai rata-rata 76,8 .

\section{SIMPULAN}

Pelaksanaan pembelajaran dengan menggunakan pendekatan kontekstual pada materi pembelajaran menulis surat resmi, telah terlaksana dengan baik. Penggunaan pendekatan kontekstual pada pembelajaran Bahasa Indonesia pada kompetensi menulis surat resmi dapat membantu siswa dalam mengembangkan keterampilan menulis dan dapat meningkatkan keterampilan siswa dalam menulis surat resmi. Keaktivan siswa meningkat dengan adanya perubahan pada kegiatan guru yang lebih banyak melibatkan siswa dan guru membacakan hasil tulisan yang terbaik sehingga siswa termotivasi untuk membuat surat resmi yang lebih baik agar mendapat nilai yang baik. 


\section{DAFTAR PUSTAKA}

Armariena, D. N. (2017). Penulisan Narasi Mahasiswa dengan Metode Copy the Master dalam Menghidupkan Kartakter, Perilaku dan Konflik Tokoh. Prosiding Dosen Universitas PGRI Palembang Edisi 9, 10-19. Palembang: Universitas PGRI Palembang.

Armariena, D. N. (2019). Penulisan Makalah Mahasiswa pada MKU Bahasa Indonesia dengan Metode Mind Mapping. Jurnal Wahana Didaktika. Vol 17 No 2 Mei 2019.

Djuharie, Setiawan dkk. (2001). Surat Menyurat Serbaguna Panduan Korespondensi Bahasa Indonesia. Bandung: Yrama Widia.

Hernowo. (2005). Strategi Belajar Mengajar. Bandung: Pustaka Setia.

Nurjamal, Daeng dkk. (2011). Terampil Berbahasa Menyusun Karya Tulis Akademik, Memandu Acara (MC-Moderator), dan Menulis Surat. Bandung: Alfabeta.

Sanjaya, Wina. (2008). Strategi Pembelajaran Berorientasi Standar Proses Pendidikan. Jakarta: Kencana.

Wiyanto, Asul. (2004). Terampil Menulis Paragraf. Jakarta: PT Gramedia Widiasarana Indonesia. 